University of Windsor

Scholarship at UWindsor

$10-2013$

\title{
Identifying and Differentiating Key Employees from Owners and Other Employees in SMEs
}

Francine K. Schlosser

Odette School of Business, University of Windsor

Follow this and additional works at: https://scholar.uwindsor.ca/odettepub

Part of the Business Commons

\section{Recommended Citation}

Schlosser, Francine K.. (2013). Identifying and Differentiating Key Employees from Owners and Other Employees in SMEs. Journal of Small Business Management, 53 (1).

https://scholar.uwindsor.ca/odettepub/112

This Article is brought to you for free and open access by the Odette School of Business at Scholarship at UWindsor. It has been accepted for inclusion in Odette School of Business Publications by an authorized administrator of Scholarship at UWindsor. For more information, please contact scholarship@uwindsor.ca. 
Running Head: Key Employees in SMEs

\title{
DIFFERENCES IN KEY EMPLOYEES BY FIRM AGE AND ENTREPRENEURIAL ORIENTATION
}

\author{
Francine Schlosser \\ University of Windsor, Canada
}

Citation: Schlosser, Francine, Differences in Key Employees by Firm Age and Entrepreneurial Orientation, RENT XXVI Research in Small Business and Entrepreneurship, European Council for Small Business, 2012, November. 
Key Employees in SMEs

\section{Differences in Key Employees by Firm Age and Entrepreneurial Orientation}

\section{Introduction}

On average in 2007, just over 5.1 million employees on payroll, or 48 percent of the total private sector labour force worked for small enterprises (those with fewer than 100 employees), constituting $98 \%$ of all businesses in Canada (Industry Canada, 2009). Although human capital is an important indicator of organizational success (Levent Altinay, Altinay, \& Gannon, 2008; Manigart et al., 2007), small firms are often faced with more competition for human capital (Marchington, Carroll, \& Boxall, 2003), less access to a quality labour pool (Hornsby \& Kuratko, 1990) and experience greater rates of failure (e.g., Strotmann, 2007) than larger firms. Additionally, in a replication of their earlier study, Hornsby and Kuratco (2003) concluded that there had been little advancement in the sophistication of HR practices over the past 10 years. Despite this evidence much entrepreneurial research focuses upon firms that target high growth, and who quickly leave small business status behind. Yet this is an important oversight because SMEs are faced with greater challenges than larger organizations in retaining and attracting key employees (e.g., Ritchie 1993 in Carroll, Marchington, Earnshaw, \& Taylor, 1999).

This research aims to better understand the types of individuals who are considered to be key employees by SME owners. Researchers have related firm traits and owner characteristics to SME survival (Bates, 2005). But, despite the fact that employees are an important part of strategy implementation and a reflection of firm culture, there is scant research on key employees who do not hold an ownership stake in small businesses. 
Additionally researchers that have compared entrepreneurs to their employees have not distinguished between key employees and other employees. Hence, this research will examine:

1) How do the profiles of SME owners and their key employees differ? Given that previous researchers have noted that differences in human resources might influence the nature of a firm's success (e.g., Baron, 2003; Hmieleski \& Ensley, 2007), I also consider: 2) How do the profiles of key employees differ when we take into account firm age and entrepreneurial orientation?

Extant literature considers and defines concepts such as effective employees, human resources, and human capital, but appears to overlook the existence of certain employees that are perceived by small business owners to be "key" to the effective management of their businesses. Consequently this research attempts to understand employees that represent a key source of human capital upon which the SME owner relies. In this research a key employee is defined as an employee that an owner 1 ) believes is the most effective, 2) relies upon and trusts to get the job done, and 3) whose work is perceived by the entrepreneur to contribute the most to the success of the venture (Schlosser, 2013).

The purpose of this research is to build an understanding of the differences among key employees related to the entrepreneurial orientation and age of SMEs. I contribute to new knowledge as I explore how key employees in SMEs are perceived by their employers. First I describe the current literature relating to human capital in SMEs and then I respond to the gap in the literature surrounding key employees with an empirical study of entrepreneurs and their key employees. SME owners are asked to describe their key employees. In contrast with recent 
attention paid to high tech and financial services industries, I investigate the profiles of key employees across firms in diverse industries with differing dynamics and resource availability. Recent research has indicated that there are industry differences in entrepreneurial orientation (e.g., Wiklund \& Shepherd, 2005).

\section{Differentiating Key Employees}

Overall firm human capital (including knowledge and experience) predicts success. Although employees are an important part of strategy implementation, and indeed reflect firm culture, to date little research has examined the phenomena of key employees critical to small business success. Heneman, Tansky, and Camp (2000) concluded that the topic of staffing was less emphasized in the research literature than it was by actual entrepreneurs. Admittedly, researchers have investigated the dynamics of top management teams (e.g., Ensley, Pearson, \& Pearce, 2003) and of intrapreneurship (Altinay, 2005, p. 417) but this research usually reflects large ventures, not SMEs.

There is little research differentiating key employees and all other employees. Only recently have researchers examined and defined key employees (e.g., Aime, Johnson, Ridge, and Hill, 2010; Cosack, Guthridge, and Lawson, 2010). A more recent definition more closely defines a key employee "as the employee an owner 1) believes is the most effective, 2) relies upon and trusts to get the job done, and 3) whose work is perceived by the entrepreneur to contribute the most to the success of the venture" (Schlosser, 2013).

In terms of key employee emergence, other theories contribute to understanding of the entrepreneur's identification of and relationship with key employees. For example, previous 
entrepreneurship researchers have identified several characteristics related to entrepreneurial founders or team, such as proactiveness, risk-taking, and innovativeness (Cauthorn 1989), cognitive style (Mitchell, Busenitz, Lant, McDougall, Morse, and Smith 2002), education (Ucsbaran, Westhead and Wright 2008) and achievement (Collins, Hanges, and Locke 2004). Recent research has identified human resource issues related to functional similarity of founding teams (e.g., Schjoedt, Monsen, Pearson, Barnett, \& Chrisman, 2013). In particular, Chen (2013) concluded that although employers tended to choose homogenous founding team members, they were more likely to select early employees who were functionally different, and new ventures with functionally different owners and employees predicted both first and second stage venture success (sales). Finally, her study noted that previous shared work experiences / ties predicted employer choice of early employees.

These characteristics may inform understanding of key employee characteristics and behaviours.

\section{Venture Age}

The age of small businesses is often used as a basic measure of success because failure rates for small businesses decline over time. For example, in Canada, $96 \%$ of businesses survive the first year of operation, $85 \%$ survive after three years, and $70 \%$ survive after five years (Industry Canada, 2009). Previous researchers have demonstrated that as SMEs age, their owners recruit or outsource to employees who supplement and diversify their skill base, usually beginning with accounting (Ardichvili, Harmon, Cardozo, Reynolds, \& Williams, 1998).

Ostensibly, it allows the owner to pursue their plans, while the key employee stabilizes the 
business venture. In this way, Thakur (1999) concluded that key employees can act as a mechanism to release managerial resources and allow a firm to survive and grow. As ventures age and grow, have more functions and roles, and the entrepreneur will experience a transition from entrepreneurial to managerial roles, and as more of a manager they need people who complement their skills, so they hire those who are different (Leung 2006). On the other hand, in new ventures (which are typically small), functional roles are not clearly distributed and the interpersonal aspects are more critical. Accordingly, I hypothesize:

Hypothesis 1: Owners of older SMEs will perceive less similarity between themselves and their key employees than owners of younger SMEs.

\section{Entrepreneurial Orientation}

High growth firms are often characterized by an entrepreneurial orientation (EO), that is a strategic direction based upon entrepreneurial precepts (e.g., Child, 1972; Miles \& Snow, 1978; Mintzberg, 1973). Strategically, firms with an entrepreneurial orientation take calculated risks, and demonstrate pro-activeness and innovation (Miller, 1983; Morris \& Paul, 1987) which are predictive of firm performance factors (e.g., Smart \& Conant, 1994; Zahra, 1991).

Researchers have extensively studied and debated the dimensions of entrepreneurial orientation; hence, the construct of entrepreneurial orientation is now well-established and its measurement validated (Covin \& Lumpkin, 2011). Entrepreneurial orientation is measured using organisational growth and innovation indicators. Although the academic and practitioner literatures do not usually distinguish between very high growth/entrepreneurial businesses and smaller enterprises that vary on growth and sustainability dimensions, the sheer number of 
SMEs and their collective economic impact on North America indicates that there is merit in studying differences in smaller businesses. There seems to be a tendency to consider polar opposites instead of considering fluctuations and differences along the length of the growth and size continuums.

An entrepreneurial orientation represents the collective values and beliefs of the group of entrepreneurial individuals who work in the organization. An entrepreneurial SME strongly reflects the personality, values and growth goals of the entrepreneurial owner yet the attitudes and behaviours of both the owner and employees contribute to organizational entrepreneurial orientation (Schlosser \& Todorovic, 2006). A study by Heneman, Tansky and Camp (2000) concluded that growth oriented CEO/founders were more concerned about matching an employee to the organisation. More recently, Chen (2013) indicated that entrepreneurs will choose co-founders that are similar to themselves but employees who are functionally different. However, her longitudinal study noted that the skills diversity of the founding team became more crucial to firm performance as the firm aged. Thus, it might be argued that they will choose employees similar to themselves and who fit well with the entrepreneurial SME. Hence, I hypothesize:

Hypothesis 2: The more that entrepreneurs perceive key employees to be similar to themselves the higher the SME entrepreneurial orientation.

\section{Testing}

In this section, I test these hypotheses across a number of industries by asking entrepreneurs to describe the demographic, attitudinal and behavioural profiles of their key employees, the roles of the employees and methods used to identify and recruit them. 
Key Employees in SMEs

Method. A cross-sectional field survey was designed that asked each SME owner to select one key employee and rate him/her on a variety of attitudinal and behavioural measures. The survey instructed the owner to choose an employee that the owner felt comfortable relying upon, although not necessarily one that was 'liked' the most, but someone that the owner trusted to 'get the job done'. The survey also asked the owners to describe the firm's entrepreneurial orientation and venture age. First, 1000 surveys were mailed out to the managing owners of a stratified sample of independent SMEs in Southwestern Ontario. Ten businesses from each letter of the alphabet were selected from the online membership of the directories of multiple Chambers of Commerce and Entrepreneurial "meet-up" groups. Of the original mailout, 150 were undeliverable due to moving or closing of the businesses. I followedup with two phone calls, email and later followed-up in person with those who were members of entrepreneurial meet-up groups operating in the region. After the elimination of those with more than $50 \%$ missing data, there were 129 responses. A response rate of 15.1 per cent is low but not unusual in surveys of SMEs, given the reluctance of the population (Newby, Watson, \& Woodliff, 2003). Table 1 depicts demographic frequencies for employer participants and their key employees and venture age and size. More than $50 \%$ of the ventures had less than $10 \%$ turnover. Three quarters of employees were compensated through straight salary. Only $28 \%$ of the employers had made any plans for succession, and $15 \%$ of the respondents believed that this key employee would be the best successor. Twenty per cent of the key employees had owned their own businesses in the past. More than half of the employees had worked with the employer for more than 5 years and the average length of time the key employee had worked in this particular venture was similar to the average age of the venture (approximately 5 years). 
Most owners and employees were Caucasian. The responses represented eight industry categories: Retail 20.2\%, Manufacturing 11.6\%, Restaurant 6.2\%, Health and Professional Services $27.1 \%$, Tourism 7.8\%, Other services 9.3\%, Construction and Home Improvement7.0\%, High Tech=7.0\%, and Missing 3.9\%.

Insert Table 1 about here

Measures. Previous literature had identified potential differences between entrepreneurs and employees in innovation, self-esteem, risk-propensity, creativity, human capital, initiative, and demographic profiles. Additionally, Schlosser (forthcoming) concluded that entrepreneurs and employees had developed different profiles connected to responsibility, learning orientation, and work-family balance. Consequently the measures reflected all of these variables. The operationalization utilized previously published measures in organizational behaviour research. Table 2 identifies the measures, alphas, authors and example items. All variables in Table 2 were measured at the individual level, with the owners rating only their key employees. The work family segmentation scale (Edwards \& Rothbard, 1999; Rothbard, Phillips, \& Dumas, 2005) was used to reflect some of the concerns around roles and responsibilities that arose out of the qualitative study. The human development and utilization scale (adapted from Rausch, Frese, \& Utsch, 2005) and the learning goal scale (Button, Mathieu, \& Zajac, 1996) operationalized the learning and development highlighted in the qualitative study. 
At a firm level, entrepreneurial orientation was measured with Covin et al.'s (1989;

1986) scale ( $\alpha=.828)$. For example, entrepreneurs were asked "In dealing with competitors this firm...", and respondents would note their answer on a scale with anchors "Is very seldom the first business to introduce new product/services administrative techniques operating technologies etc." to "Is very often the first business to introduce new products/services administrative techniques operating technologies etc." Additionally, I measured venture age and turnover by asking employers to note their average annual employee turnover (\%).

Insert Table 2 about here

Scales were analysed for reliability and items eliminated with low item-to-total correlations. The items were then aggregated into an average score for each scale. Discriminant validity was assessed by correlating all measures adopted in the study and measuring the correlation coefficients against the alpha coefficients. As no correlation coefficient was higher than the alpha coefficient of the scale, the scales used in the study exhibited discriminant validity.

Analysis. To answer questions three and four, I performed separate regressions of firm level entrepreneurial orientation and venture age on key employee attributes. For hypotheses one and two I created dummy variables representing same gender, same ethnicity, same age bracket, same education and perceptions of similarity between entrepreneur and employee. Specifically, I coded gender, age, education and ethnicity into new dummy variables representing matching of entrepreneur and employee. I also dichotomized the metric 
perceived similarity variable into high and low perceived similarity at the construct mean (3.45). I performed two separate regressions: first, I regressed venture age on similar gender, ethnicity, age and perceptions of similarity $(\mathrm{H} 1)$. Then, I regressed entrepreneurial orientation on similar gender, ethnicity, age and perceptions of similarity.

Results. The means, standard deviations and zero order correlations of all measures are noted in Table 3. Perceived similarity between entrepreneurs and key employees was significantly correlated with all variables but work-family balance and venture age. Creativity was significantly related to all variables but self-esteem and work-family balance, and was negatively related to the latter. Work family balance was not significantly related to any of the variables and was weakly and negatively related to most of them. Venture age and firm entrepreneurial orientation were significantly negatively correlated.

Table 4 shows the results when firm entrepreneurial orientation was regressed on characteristics of key employees. The adjusted $R^{2}=.322$, indicating that $32 \%$ of the variance in entrepreneurial orientation was explained by these characteristics. Higher employee innovation and human development/utilization and lower employee human capital were significant predictors of firm entrepreneurial orientation.

The regression of venture age on key employee characteristics was significant, with an adjusted $\mathrm{R}^{2}=.266$. The results shown in Table 5 indicate that older SMEs were more likely to have key employees with higher perceived self-esteem and human capital and when there was lower perceived similarity between entrepreneur and employee,. 
The hypotheses considered whether venture age $(\mathrm{H} 1)$ and entrepreneurial orientation $(\mathrm{H} 2)$ were related to high perceived and actual similarity between the entrepreneur and key employee. I performed separate regressions of firm entrepreneurial orientation and age of venture on dummy variables representing high perceived similarity (scoring above the mean response), matched female gender, matched male gender, matched ethnicity, matched age, and matched education. Both the regressions for entrepreneurial orientation (adjusted $\mathrm{R}^{2}=$ $.062, p=.031$ ) and venture age (adjusted $R^{2}=.213, p=.000$ ) were significant and are included in Tables 6 and 7. Essentially, older SMEs were more likely to reflect dissimilar entrepreneurs and key employees in gender, age and perceived similarity. Education and ethnicity were not significant, likely due to the small sample size and the larger number of categories creating nonnormality. In contrast, SMEs were significantly likely to be younger and highly entrepreneurial when the entrepreneur perceived the key employee to be similar rather than dissimilar, in work habits and personality.

Insert Tables 3, 4, 5, 6, and 7 about here

There were 43 responses to an open-ended question inquiring about the main contribution of key employees. These fell into six themes led by reliability (12 responses), skilled (12 responses), and role-specific (12 responses). In contrast the last three themes: employee independence (2), enthusiasm (3) and innovation (2) were much less prominent.

\section{Discussion}


Key Employees in SMEs

\section{Profiles of Key Employees}

The survey of entrepreneurs about their key employees highlighted differences in how firm entrepreneurial orientation and firm age related to the attitudes and behaviours of key employees. Innovative employees who were involved in making decisions about the business (high human development and utilization) were considered to be key employees in entrepreneurial SMEs. Respondents indicated that these key employees were significantly less likely to have high levels of training, work knowledge and formal qualifications. Perhaps this suggests that as they involved themselves in the business, they were able to adapt and learn on the job, and innovate without being hampered by traditional views incurred through formal training.

\section{Entrepreneur / Key Employee Similarity}

Young entrepreneurial ventures were more likely to employ key employees who were perceived to be similar to entrepreneurial owners, whereas older firms were more likely to employ key employees that differed from the entrepreneurial owners (both perceived and actual differences).

Hypothesis 1 was supported, which indicated that venture age was significantly negatively related to actual demographic similarity and perceived personality and work habit similarity. The average age of the ventures was the same as the average tenure of the key employees. This appears to support Leung (2006), who believed entrepreneurs and employees shared a similarity of background and personal aspirations at the start, but then as the venture aged, progressed to the hiring of employees who had functional diversity and shared business visions. 
Key Employees in SMEs

Hypothesis 2 was also supported, because firm entrepreneurial orientation was significantly and positively related to personality similarity and work habit similarity. Perhaps employees with an entrepreneurial profile aid in establishing a firm entrepreneurial orientation, but will eventually strike out on their own, hurting the original business' survival. Accordingly my results imply that the profiles of employees who contribute to firm entrepreneurial orientation may differ from those employees who contribute to it over a longer period of time.

\section{Growth, Age and Human Resource Practices}

Firm entrepreneurial orientation was significantly negatively related to age of venture. The sample consisted of firms that employed less than 75 employees. This snapshot of small firms may help to categorize SMEs into categories of growth versus non-growth. It might be that some firms do not prioritize growth. The more entrepreneurial ones would grow at higher rates, and would not remain indefinitely as an SME.

\section{Contributions to Scholarship and Practice}

To summarize, entrepreneurial ventures were more likely to employ innovative, involved employees who were perceived to be similar to entrepreneurs, whereas SMEs that survived over a period of time were more likely to employ key employees that differed from the owner in demographics and perceived personality and work habits but scored high in selfesteem, business knowledge and reliability. The age of the SME was significantly negatively correlated with firm level entrepreneurial orientation.

This study contributes to our understanding of talent identification in SMEs; a topic that is lacking research in the strategy, organizational behaviour and business economics literature. The research identifies potential differences in the attitudes and behaviours of key employees 
in entrepreneurial SMEs and in surviving SMEs, by distinguishing key employees from other employees and from the entrepreneurial owner. This fills a gap in previous literature which focuses only upon general differences between entrepreneurs and non-entrepreneurs.

Additionally, the study provides insights into both actual and perceived differences.

As a consultant and educator who frequently works with small business start-ups, I found the results of this study fascinating and quite practical. The question "Should entrepreneurs try to recruit individuals who are similar or not?" is one we've oft debated. The results might help those starting new businesses to select key employees that fit their vision for their venture. The research also identifies key traits and behaviours that might be ascertained through the recruitment and interview process.

\section{Limitations of the Study and Future Research Directions}

This research profiled key employees who choose to work for an entrepreneur rather than starting their own businesses. However, future research might examine key employee retention in more detail, as human talent retention is a key piece of firm survival and more challenging for small businesses in general. The current study was cross-sectional, and relied upon only one source of information, hence future studies might consider matching both entrepreneur and employee responses and profiles across a large quantitative study for more generalizable results. Analysis of industry differences was inconclusive, due to the small sample sizes and future studies should expand on industry differences.

This study asked owners to describe the employee that they currently most rely upon and seemed to have relied upon for a significant period of time, and consequently provides a 
rather static view of key employees. Future studies might test the implication of temporal effects on desired employee characteristics and relationships with key employees.

\section{Conclusion}

Talent management is challenging in small firms, where owners are often stretched thin by multi-tasking, and do not have the time or the know-how to employ a consistent set of HR practices. This research responds to entrepreneurs, HR practitioners, and academics by describing key employees who contribute to SMEs. 
Key Employees in SMEs

\section{Bibliography}

Aime, F., S. Johnson, J. Ridge, and A. Hill (2010). The Routine may be Stable but the Advantage is Not: Competitive Implications of Key Employee Mobility, Strategic Management Journal, 31, 75-87.

Altinay, L. (2005). The intrapreneur role of the development directors in an international hotel group Service Industries Journal 25(3), 403 - 419

Altinay, L., Altinay, E., \& Gannon, J. (2008). Exploring the relationship between the human resource management practices and growth in small service firms Service Industries Journal, 28(7), 919-937.

Ardichvili, A., Harmon, B., Cardozo, R., Reynolds, P., \& Williams, M. (1998). The New Venture Growth: Functional Differentiation and the Need for Human Resource Development Interventions Human Resource Development Quarterly, 9, 55-70.

Baron, R. A. (2003). Editorial: Human resource management and entrepreneurship: Some reciprocal benefits of closer links Human Resource Management Review 13 253-256.

Bates, T. (2005). Analysis of young, small firms that have closed: Delineating successful from unsuccessful closures. Journal of Business Venturing, 20, 343-358.

Button, S. B., Mathieu, J. E., \& Zajac, D. M. (1996). Goal orientation in organizational research: a conceptual and empirical foundation. Organizational Behavior and Human Decision Processes, 67, 26-48.

Carroll, M., Marchington, M., Earnshaw, J., \& Taylor, S. (1999). Recruitment in small firms: Processes, methods and problems. Employee Relations, 21(3), 236-250.

Cauthorn, R. C. (1989). Contributions to a Theory of Entrepreneurship. New York: Garland Publishing.

Chen, J. (2013) Firm Characteristics and Employee Entrepreneurs' Choice of Cofounders and Early Employees. Presentation to Academy of Management Annual Meeting, Orlando. August 13, 2013.

Child, J. (1972). Organization structure and strategies of control - A replication of the Ashton study. Administrative Science Quarterly, 17(2), 163.

Collins, C. J., Hanges, P. J., \& Locke, E. A. (2004). The relationship of achievement motivation to entrepreneurial behavior: A meta-analysis. Human Performance, 17(1), 95-117. 
Cosack, S., M. Guthridge, and E. Lawson (2010). Retaining key employees in times of change. McKinsey Quarterly, 3, 135-139.

Covin, J., \& Lumpkin, G. (2011). Entrepreneurial Orientation Theory and Research: Reflections on a Needed Construct. Entrepreneurship Theory \& Practice, 35(5), 855-872.

Covin, J., \& Slevin, D. (1989). Strategic management of small firms in hostile an benign environments. Strategic Management Journal, 10(1), 75-88.

Covin, J. G., \& Slevin, D. (1986). The development and testing of an organization-level entrepreneurship scale. Frontiers of Entrepreneurship Research.

Edwards, J. R., \& Rothbard, N. P. (1999). Work and family stress and well-being: An examination of person-environment fit in the work and family domains. Organizational Behavior and Human Decision Processes, 77(2), 85-129.

Farmer, S. M., Tierney, P., \& Kung-Mclntyre, K. (2003). Employee creativity in Taiwan: An application of role identity theory. Academy of Management Journal, 46(5), 618-630.

Frese, M., Fay, D., Hilburger, T., Leng, K., \& Tag, A. (1997). The concept of personal initiative: Operationalization, reliability and validity in two German samples. Journal of Occupational and Organizational Psychology, 70(2), 139-161.

Heneman, R., Tansky, J., \& Camp, S. (2000). Human resource management practices in small and medium-sized enterprises: Unanswered questions and future research perspectives Entrepreneurship Theory and Practice 25 11-26

Hmieleski, K. M., \& Ensley, M. D. (2007). A contextual examination of new venture performance: Entrepreneur leadership behavior, top management team heterogeneity, and environmental dynamism. Journal of Organizational Behavior, 28, 865-889.

Hornsby, J., \& Kuratko, D. (1990). Human resource management in small business: Critical issues for the 1990s. Journal of Small Business Management, 28, 9-18.

Hornsby, J., \& Kuratko, D. (2003). Human resource management in U.S. small business: A replication and extension. Journal of Developmental Entrepreneurship, 8(73-92).

Hsieh, Y.-M., \& Hsieh, A.-T. (2001). Enhancement of Service Quality with Job Standardisation Service Industries Journal, 21(3), 147-166.

Industry Canada. (2009). Key Small Business Statistics January 2009. Retrieved. from www.ic.gc.ca/sbstatistics. 
Leung, A., Zhang, J., Wong, P. K., \& Foo, M. D. (2006). The use of networks in human resource acquisition for entrepreneurial firms: Multiple "fit" considerations. Journal of Business Venturing, 21, 664-686.

Manigart, S., Collewaert, V., Wright, M., Pruthi, S., Lockett, A., Bruining, H., et al. (2007). Human capital and the internationalisation of venture capital firms. International Entrepreneurship and Management Journal, 3(1), 109-134.

Marchington, M., Carroll, M., \& Boxall, P. (2003). Labour scarcity and the survival of small firms: A resource-based view of the road haulage industry. Human Resource Management Journal, 13, 5-22.

McCline, R. L., Bhat, S., \& Baj, P. (2000). Opportunity Recognition: An exploratory investigation of a component of the entrepreneurial process in the context of the health care industry. Entrepreneurship Theory and Practice, Winter, 81-94.

Miles, R. E., \& Snow, C. C. (1978). Organizational Strategy, Structure, and Process. Toronto: McGraw-Hill Book Company.

Miller, D. (1983). The Correlates of Entrepreneurship in Three Types of Firms. Management Science, 29(7), 770-792.

Mintzberg, H. (1973). The Nature of Managerial Work. New York: Harper \& Row.

Mitchell, R. K., Busenitz, L. W., Lant, T., McDougall, P. P., Morse, E. A., \& Smith, J. B. (2002). Toward a theory of entrepreneurial cognition: Rethinking the people side of entrepreneurship research. Entrepreneurship Theory and Practice, Winter, 93-104.

Morris, M. H., \& Paul, G. W. (1987). The Relationship Between Entrepreneurship and Marketing in Established Firms. Journal of Business Venturing, 2(3), 247-260.

Newby, R., Watson, J., \& Woodliff, D. (2003). SME survey methodology: Response rates, data quality, and cost effectiveness. Entrepreneurship Theory and Practice, Winter, 163-172.

Rausch, A., Frese, M., \& Utsch, A. (2005). Effects of human capital and long-term human resources development and utilization on employment growth of small-scale businesses: A causal analysis. Entrepreneurship Theory and Practice, November, 681698.

Robinson, P. B., Stimpson, D. V., Huefner, J. C., \& Hunt, H. K. (1991). An attitude approach to the prediction of entrepreneurship. Entrepreneurship Theory and Practice, Summer, 13-31. 
Rothbard, N. P., Phillips, K. W., \& Dumas, T. L. (2005). Managing Multiple Roles: Work-Family Policies and Individuals' Desires for Segmentation. Organization Science. , 16(3), 243258.

Schjoedt, L., Monsen, E., Pearson, A., Barnett, T., \& Chrisman, J. J. (2013). New Venture and Family Business Teams: Understanding Team Formation, Composition, Behaviors, and Performance. Entrepreneurship Theory and Practice, 37(1), 1-15.

Schlosser, FK., (forthcoming). Identifying and Differentiating Key Employees from Owners and Other Employees in SMEs, forthcoming in the Journal of Small Business Management.

Schlosser, F. K., \& Todorovic, Z. W. (2006). Entrepreneurial charisma: A key to employee identification? Journal of Small Business and Entrepreneurship, 19(1), 49-62.

Smart, D. T., \& Conant, J. S. (1994). Entrepreneurial orientation, distinctive marketing competencies and organizational performance. Journal of Applied Business Research, 10(3), 28-39.

Strotmann, H. (2007). Entrepreneurial survival. Small Business Economics, 28, 87-104.

Thakur, S. P. (1999). Size of investment, opportunity choice and human resources in new venture growth: Some typologies Journal of Business Venturing, 14 (3), 283-309

Wiklund, J., \& Shepherd, D. A. (2005). Entrepreneurial orientation and small business performance: A configurational approach. Journal of Business Venturing, 20, 71-91.

Zahra. (1991). Predictors and Financial Outcomes of Corporate Entrepreneurship: An Exploratory Study. Journal of Business Venturing, 6(4), 259-286. 


\section{Table 1:}

\section{Frequencies}

\begin{tabular}{|c|c|c|}
\hline Demographic variables & $\begin{array}{c}\text { Employer } \\
\text { Number of cases in each } \\
\text { category } \\
(n=129) \\
\end{array}$ & $\begin{array}{c}\text { Employee } \\
\text { Number of cases in each } \\
\text { category } \\
(n=129)\end{array}$ \\
\hline \multicolumn{3}{|l|}{ Gender } \\
\hline Male & 89 & 62 \\
\hline Female & 34 & 60 \\
\hline Missing Cases & 6 & 7 \\
\hline \multicolumn{3}{|l|}{ Age } \\
\hline $18-25$ years & 13 & 20 \\
\hline $26-40$ years & 45 & 52 \\
\hline $41-55$ years & 47 & 1 \\
\hline $56-65$ years & 16 & 13 \\
\hline Over 66 & 5 & 2 \\
\hline Missing Cases & 3 & 1 \\
\hline \multicolumn{3}{|l|}{ Education } \\
\hline High School & 23 & 34 \\
\hline College & 29 & 36 \\
\hline University & 70 & 49 \\
\hline Trades & 3 & 6 \\
\hline Missing Cases & 4 & 4 \\
\hline \multicolumn{3}{|l|}{ Venture Age } \\
\hline Less than 1 year & & 17 \\
\hline 1 to less than 5 years & & 54 \\
\hline 5 years to less than 10 years & & 22 \\
\hline 10 years or more & & 35 \\
\hline Missing Cases & & 1 \\
\hline \multicolumn{3}{|l|}{ Venture Size } \\
\hline 1-5 employees & & 44 \\
\hline 6-25 employees & & 37 \\
\hline 26-50 employees & & 24 \\
\hline 51-100 employees & & 15 \\
\hline 101-200 employees & & 7 \\
\hline Over 200 employees & & 1 \\
\hline Missing Cases & & 1 \\
\hline
\end{tabular}

Source: Author 
Table 2

Measures

\begin{tabular}{|c|c|c|}
\hline Variable and Alpha & Author & Example Item (s) \\
\hline $\begin{array}{l}\text { Behavioural measure for } \\
\text { innovation ( } 8 \text { item) } \\
\alpha=.665\end{array}$ & $\begin{array}{l}\text { (Robinson, } \\
\text { Stimpson, Huefner, } \\
\text { \& Hunt, 1991) }\end{array}$ & $\begin{array}{l}\text { Most of this employee's time is spent } \\
\text { working on several business ideas at the } \\
\text { same time. }\end{array}$ \\
\hline $\begin{array}{l}\text { Behavioural measure for self } \\
\text { esteem ( } 2 \text { item) } \\
\alpha=.723\end{array}$ & $\begin{array}{l}\text { (Robinson et al., } \\
\text { 1991) }\end{array}$ & $\begin{array}{l}\text { This employee often puts on a show to } \\
\text { impress the people (s)he works with } * R\end{array}$ \\
\hline $\begin{array}{l}\text { Risk willingness ( } 2 \text { item) } \\
\alpha=.746\end{array}$ & $\begin{array}{l}\text { (McCline, Bhat, \& } \\
\text { Baj, 2000) }\end{array}$ & $\begin{array}{l}\text { This employee takes chances with his/her } \\
\text { career choices. }\end{array}$ \\
\hline $\begin{array}{l}\text { Employee creativity scale ( } 4 \\
\text { item) } \\
\alpha=.747\end{array}$ & $\begin{array}{l}\text { (Farmer, Tierney, \& } \\
\text { Kung-McIntyre, } \\
\text { 2003) }\end{array}$ & $\begin{array}{l}\text { This employee is a good role model for } \\
\text { creativity. }\end{array}$ \\
\hline $\begin{array}{l}\text { Human capital measure ( } 3 \text { item) } \\
\alpha=.71\end{array}$ & $\begin{array}{l}\text { (Rausch et al., } \\
\text { 2005) }\end{array}$ & $\begin{array}{l}\text { This employee is well-trained to do this } \\
\text { work. }\end{array}$ \\
\hline $\begin{array}{l}\text { Human development and } \\
\text { utilization measures ( } 2 \text { item) } \alpha= \\
.681\end{array}$ & $\begin{array}{l}\text { Adapted from } \\
\text { (Rausch et al., } \\
\text { 2005) }\end{array}$ & $\begin{array}{l}\text { How involved is this employee in making } \\
\text { decisions about the business? (never } \\
\text { participates to always participates) }\end{array}$ \\
\hline $\begin{array}{l}\text { Perceived Similarity ( } 3 \text { item) } \\
\alpha=.845\end{array}$ & & $\begin{array}{l}\text { My work habits are similar to the work } \\
\text { habits of this employee. }\end{array}$ \\
\hline $\begin{array}{l}\text { Personal initiative scale (7 item) } \\
\alpha=.839\end{array}$ & $\begin{array}{l}\text { (Frese, Fay, } \\
\text { Hilburger, Leng, \& } \\
\text { Tag, 1997) }\end{array}$ & $\begin{array}{l}\text { Whenever there is a chance to get actively } \\
\text { involved, this employee takes it. }\end{array}$ \\
\hline $\begin{array}{l}\text { Work family segmentation scale } \\
\text { (4 item) } \\
\alpha=.878\end{array}$ & $\begin{array}{l}\text { (Edwards \& } \\
\text { Rothbard, 1999; } \\
\text { Rothbard et al., } \\
\text { 2005) }\end{array}$ & $\begin{array}{l}\text { In your opinion, how much of the following } \\
\text { characteristics are acceptable to this } \\
\text { employee (not very much=1 to very } \\
\text { much=5). } 1 . \text { Not being required to work } \\
\text { while at home }\end{array}$ \\
\hline $\begin{array}{l}\text { Learning goal ( } 5 \text { of } 8 \text { items) } \\
\alpha=.709\end{array}$ & $\begin{array}{l}\text { (Button et al., } \\
\text { 1996) }\end{array}$ & $\begin{array}{l}\text { The opportunity to learn new things } \\
\text { appears to be important to this employee. }\end{array}$ \\
\hline
\end{tabular}

Source: Author 
Table 3

Means, Standard Deviations, and Zero-order Correlations

\begin{tabular}{|c|c|c|c|c|c|c|c|c|c|c|c|c|c|c|}
\hline & $\mathrm{n}$ & $\begin{array}{c}\text { Mean } \\
\text { (SD) }\end{array}$ & 1 & 2 & 3 & 4 & 5 & 6 & 7 & 8 & 9 & 10 & 11 & 12 \\
\hline 1.Innovation & 129 & $\begin{array}{l}3.42 \\
(.61)\end{array}$ & .67 & & & & & & & & & & & \\
\hline $\begin{array}{l}\text { 2.Self } \\
\text { Esteem }\end{array}$ & 128 & $\begin{array}{c}3.01 \\
(1.21) \\
\end{array}$ & $-.52^{* *}$ & .72 & & & & & & & & & & \\
\hline 3. Risk & 128 & $\begin{array}{l}3.55 \\
(.91)\end{array}$ & $.51^{* *}$ & $.35^{* *}$ & .75 & & & & & & & & & \\
\hline 4.Creativity & 128 & $\begin{array}{l}3.51 \\
(.76)\end{array}$ & $.57^{* *}$ & -.12 & $.59^{* *}$ & .75 & & & & & & & & \\
\hline $\begin{array}{c}\text { 5. Human } \\
\text { Capital }\end{array}$ & 128 & $\begin{array}{l}3.99 \\
(.69) \\
\end{array}$ & .17 & $.21^{*}$ & .14 & $.41^{* *}$ & .71 & & & & & & & \\
\hline 6. Initiative & 128 & $\begin{array}{l}4.31 \\
(.76) \\
\end{array}$ & $.44^{* *}$ & .13 & $.40^{* *}$ & $.70^{* *}$ & $.61^{* *}$ & .84 & & & & & & \\
\hline $\begin{array}{l}\text { 7. Learning } \\
\text { Goal }\end{array}$ & 128 & $\begin{array}{l}3.73 \\
(.62)\end{array}$ & $.45^{* *}$ & -.00 & $.46^{* *}$ & $.65^{* *}$ & $.35^{* *}$ & $.66^{* *}$ & .71 & & & & & \\
\hline 8. Similarity & 128 & $\begin{array}{l}3.45 \\
(1.0)\end{array}$ & $.48^{* *}$ & $.27^{* *}$ & $.38^{* *}$ & $.50^{* *}$ & .165 & $.47^{* *}$ & $.58^{* *}$ & .85 & & & & \\
\hline $\begin{array}{l}\text { 9. Human } \\
\text { Development }\end{array}$ & 128 & $\begin{array}{l}3.76 \\
(.91)\end{array}$ & $.25^{* *}$ & -.011 & $.35^{* *}$ & $.35^{* *}$ & $.26^{* *}$ & $.36^{* *}$ & $.35^{* *}$ & $.19^{*}$ & .68 & & & \\
\hline $\begin{array}{l}\text { 10. Work } \\
\text { Family }\end{array}$ & 128 & $\begin{array}{l}3.29 \\
(.97) \\
\end{array}$ & .06 & -.11 & -.15 & -.05 & -.11 & -.05 & -.09 & -.04 & -.14 & .88 & & \\
\hline $\begin{array}{l}\text { 11. Entrep } \\
\text { Orientation }\end{array}$ & 129 & $\begin{array}{l}3.33 \\
(.72) \\
\end{array}$ & $.40^{* *}$ & $.45^{* *}$ & $.26^{* *}$ & .09 & $.28^{* *}$ & -.10 & .09 & $.22^{*}$ & $.18^{*}$ & .14 & .83 & \\
\hline $\begin{array}{l}\text { 12. Venture } \\
\text { Age }\end{array}$ & 127 & $\begin{array}{c}3 \\
(1.0)\end{array}$ & $-.22^{*}$ & $.39^{* *}$ & $-.18^{*}$ & -.11 & $.32^{* *}$ & .09 & -.01 & $-.32^{* *}$ & -.02 & -.11 & $-.25^{* *}$ & 1 \\
\hline
\end{tabular}

Cronbach Alpha on the diagonal

Source: Author 
Table 4

Regression of Entrepreneurial Orientation on Key Employee Characteristics

\begin{tabular}{|c|c|c|c|c|c|c|c|c|c|}
\hline \multirow[b]{2}{*}{ Model } & \multirow[b]{2}{*}{$\mathrm{R}$} & \multirow[b]{2}{*}{ R Square } & \multirow[b]{2}{*}{$\begin{array}{l}\text { Adjusted R } \\
\text { Square }\end{array}$} & \multirow[b]{2}{*}{$\begin{array}{l}\text { Std. Error of } \\
\text { the Estimate }\end{array}$} & \multicolumn{5}{|c|}{ Change Statistics } \\
\hline & & & & & $\begin{array}{c}\text { R Square } \\
\text { Change }\end{array}$ & F Change & df1 & df2 & Sig. F Change \\
\hline 1 & $.613^{\mathrm{a}}$ & .375 & .322 & .59377 & .375 & 7.032 & 10 & 117 & .000 \\
\hline
\end{tabular}

Standardized

Unstandardized Coefficients Coefficients Correlations

\begin{tabular}{lrrrrrrrr} 
Model & B & \multicolumn{1}{c}{ Std. Error } & \multicolumn{1}{c}{ Beta } & \multicolumn{1}{c}{ t } & \multicolumn{1}{l}{ Sig. } & Zero-order & Partial & Part \\
\hline 1 (Constant) & 2.800 & .569 & & 4.925 & .000 & & & \\
Innovation & .368 & .133 & .312 & 2.759 & .007 & .397 & .247 & .202 \\
Self-Esteem & -.089 & .062 & -.151 & -1.442 & .152 & -.454 & -.132 & -.105 \\
Risk & .063 & .081 & .080 & .780 & .437 & .257 & .072 & .057 \\
Creativity & -.054 & .118 & -.057 & -.461 & .645 & .088 & -.043 & -.034 \\
Human Capital & -.245 & .100 & -.234 & -2.450 & .016 & -.281 & -.221 & -.179 \\
Initiative & -.201 & .128 & -.211 & -1.576 & .118 & -.099 & -.144 & -.115 \\
Learning Goal & .049 & .133 & .042 & .370 & .712 & .087 & .034 & .027 \\
Pcvd Similarity & .079 & .071 & .110 & 1.113 & .268 & .223 & .102 & .081 \\
Human Devt & .162 & .065 & .204 & 2.487 & .014 & .177 & .224 & .182 \\
Work Family & .087 & .057 & .117 & 1.534 & .128 & .141 & .140 & .112
\end{tabular}

Source: Author 
Table 5

Regression for Venture Age on Employee Characteristics

\begin{tabular}{|c|c|c|c|c|c|c|c|c|c|}
\hline \multirow[b]{2}{*}{ Model } & \multirow[b]{2}{*}{$\mathrm{R}$} & \multirow[b]{2}{*}{ R Square } & \multirow[b]{2}{*}{$\begin{array}{l}\text { Adjusted R } \\
\text { Square }\end{array}$} & \multirow[b]{2}{*}{$\begin{array}{l}\text { Std. Error of } \\
\text { the Estimate }\end{array}$} & \multicolumn{5}{|c|}{ Change Statistics } \\
\hline & & & & & $\begin{array}{l}\text { R Square } \\
\text { Change }\end{array}$ & F Change & df1 & $\mathrm{df} 2$ & Sig. F Change \\
\hline 1 & $.569^{a}$ & .324 & .266 & .88052 & .324 & 5.559 & 10 & 11 & .000 \\
\hline
\end{tabular}

\begin{tabular}{|c|c|c|c|c|c|c|c|c|c|}
\hline & & $\begin{array}{r}\text { Unstand } \\
\text { Coeffic }\end{array}$ & $\begin{array}{l}\text { ardized } \\
\text { ients }\end{array}$ & $\begin{array}{l}\text { Standardized } \\
\text { Coefficients }\end{array}$ & & & & rrelations & \\
\hline & & B & Std. Error & Beta & $\mathrm{t}$ & Sig. & Zero-order & Partial & Part \\
\hline 1 & (Constant) & 1.296 & .850 & & 1.526 & .130 & & & \\
\hline & Innovation & .058 & .202 & .035 & .288 & .774 & -.225 & .027 & .022 \\
\hline & Self-Esteem & .175 & .094 & .206 & 1.859 & .066 & .391 & .170 & .142 \\
\hline & Risk & -.013 & .121 & -.012 & -.108 & .914 & -.179 & -.010 & -.008 \\
\hline & Creativity & -.280 & .179 & -.207 & -1.570 & .119 & -.112 & -.144 & -.120 \\
\hline & Human Capital & .455 & .148 & .306 & 3.067 & .003 & .315 & .274 & .234 \\
\hline & Initiative & .115 & .189 & .085 & .608 & .544 & .093 & .056 & .046 \\
\hline & Learn Goal & .288 & .197 & .175 & 1.459 & .147 & -.013 & .134 & .111 \\
\hline & Pcvd Similarity & -.366 & .106 & -.358 & -3.470 & .001 & -.321 & -.307 & -.265 \\
\hline & Human Devt & -.077 & .097 & -.068 & -.788 & .433 & -.018 & -.073 & -.060 \\
\hline & Work Family & -.077 & .084 & -.073 & -.918 & .360 & -.110 & -.085 & -.070 \\
\hline
\end{tabular}




\section{Table 6}

\section{Regression of Age of Business Venture on High Perceived and Actual Similarity}

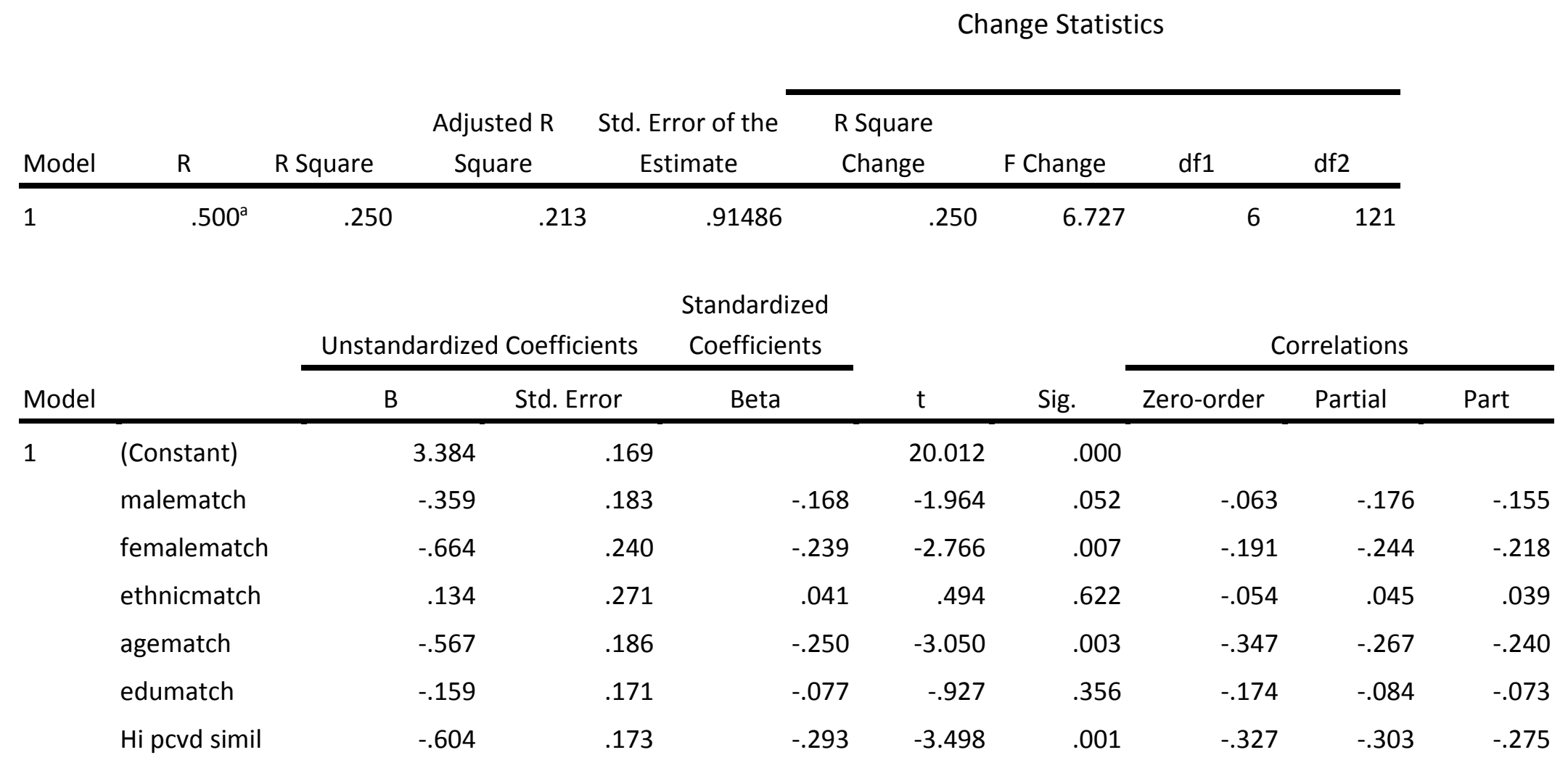

Source: Author 
Table 7

\section{Regression of Firm Entrepreneurial Orientation on High Perceived and Actual Similarity}

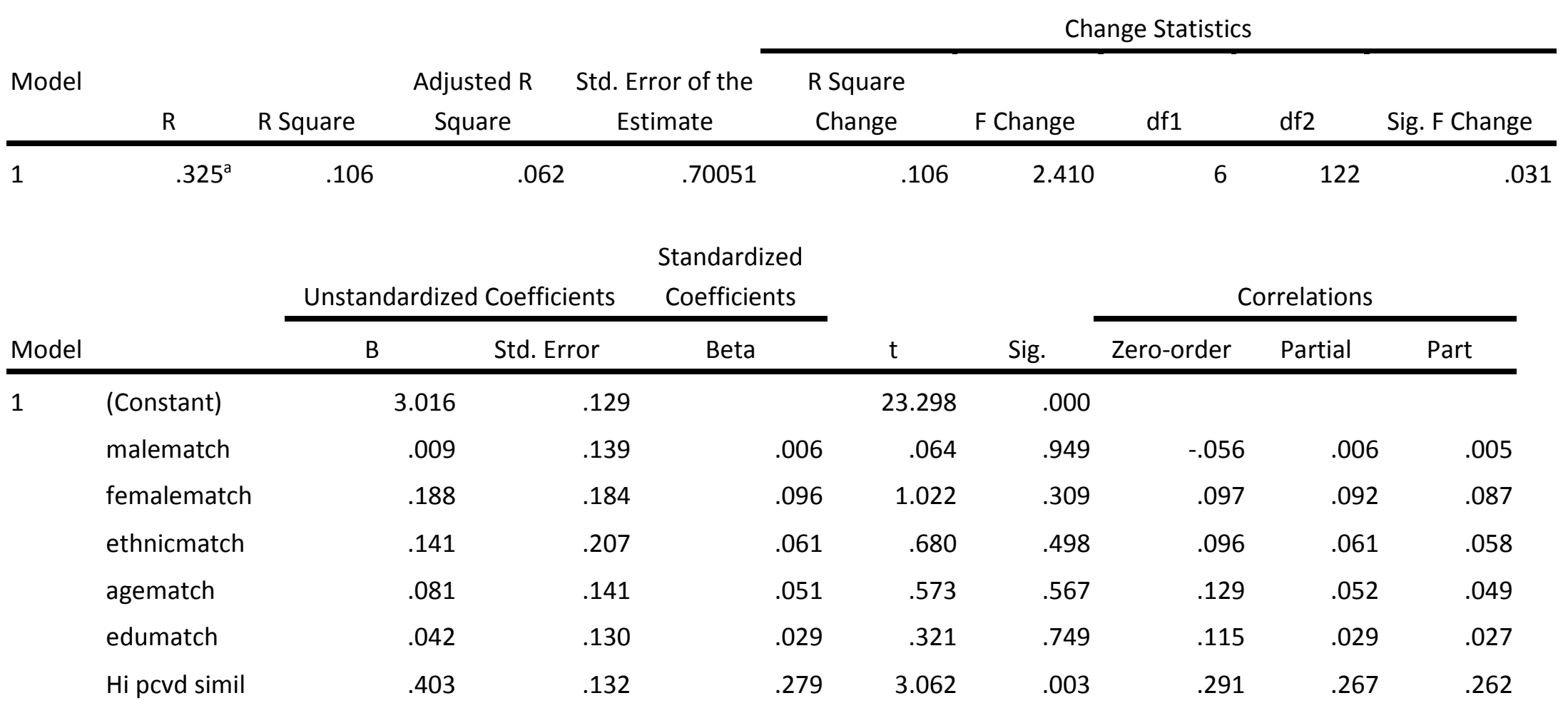

Source: Author 